\title{
The Ecology of Coral Reef Top Predators in the Papahānaumokuākea Marine National Monument
}

\author{
Jonathan J. Dale, ${ }^{1,2}$ Carl G. Meyer, ${ }^{1}$ and Christian E. Clark ${ }^{1}$ \\ ${ }^{1}$ Hawaii Institute of Marine Biology, University of Hawaii at Manoa, P.O. Box 1346, Coconut Island, Kaneohe, HI 96744, USA \\ ${ }^{2}$ Department of Zoology, Edmonson Hall, University of Hawaii at Manoa, Honolulu, HI 96822, USA
}

Correspondence should be addressed to Jonathan J. Dale, jjdale@hawaii.edu

Received 16 June 2010; Accepted 5 October 2010

Academic Editor: Robert J. Toonen

Copyright ( 2011 Jonathan J. Dale et al. This is an open access article distributed under the Creative Commons Attribution License, which permits unrestricted use, distribution, and reproduction in any medium, provided the original work is properly cited.

\begin{abstract}
Coral reef habitats in the Papahānaumokuākea Marine National Monument (PMNM) are characterized by abundant top-level predators such as sharks and jacks. The predator assemblage is dominated both numerically and in biomass by giant trevally (Caranx ignobilis) and Galapagos sharks (Carcharhinus galapagensis). A lower diversity of predatory teleosts, particularly groupers and snappers, distinguishes the PMNM from other remote, unfished atolls in the Pacific. Most coral reef top predators are site attached to a "home" atoll, but move extensively within these atolls. Abundances of the most common sharks and jacks are highest in atoll fore reef habitats. Top predators within the PMNM forage on a diverse range of prey and exert top-down control over shallow-water reef fish assemblages. Ecological models suggest ecosystem processes may be most impacted by top predators through indirect effects of predation. Knowledge gaps are identified to guide future studies of top predators in the PMNM.
\end{abstract}

\section{Introduction}

Large predators are becoming scarce on many coral reefs, with fishing thought to be a major factor in declines [1-7]. Coral reef top predators often command high market prices, providing strong economic incentives for commercial harvesting $[8,9]$. Major contributors to commercial overharvesting of coral reef predators include the shark fin fishery $[8$, $10-12]$ and the live reef food fish trade $[9,13]$. Consequently, intensive commercial exploitation has resulted in dramatic declines in reef predators in many locations $[4,13]$, and recent studies suggest even subsistence fishing can deplete reef predators $[2,5,6]$. Although less clear cut than in terrestrial systems (e.g., $[14,15])$, there is growing evidence that removal of top predators from marine ecosystems may trigger trophic cascades resulting in phase shifts $[2,6,16-19]$. In coral reef ecosystems, these shifts appear to favor algaldominated reefs populated by small planktivorous fishes and echinoderms, at the expense of reef-building scleractinian corals $[2,6,16,19]$. Collectively these studies indicate that effective conservation of top level predators is important for coral reef ecosystem health.
Science-based management and effective conservation of coral reef top predators requires a broad understanding of their ecology. We need to know which species are present, their abundance, spatial dynamics and habitat requirements, rates of growth, reproduction and mortality, diet, and ecological interactions with other species. Unfortunately, the natural ecology of top predators has already been substantially altered in heavily impacted ecosystems. For example, overfishing has resulted in extirpation of spawning aggregations of coral reef top predators such as grouper and snapper in many areas [3]. Social learning, or tradition, may play a key role in the development and repeated formation of individual spawning aggregations [20], and this knowledge may be lost when the aggregations are overharvested [3]. Empirical data from areas in which predator ecology is minimally impacted by humans would be useful for determining how we have altered predator ecology in heavily impacted areas and for setting management goals to help restore predator populations and ecosystem function. One such minimally impacted area is the Papahānaumokuākea Marine National Monument (PMNM) in the Northwestern Hawaiian Islands. The PMNM consists of a series of rocky 


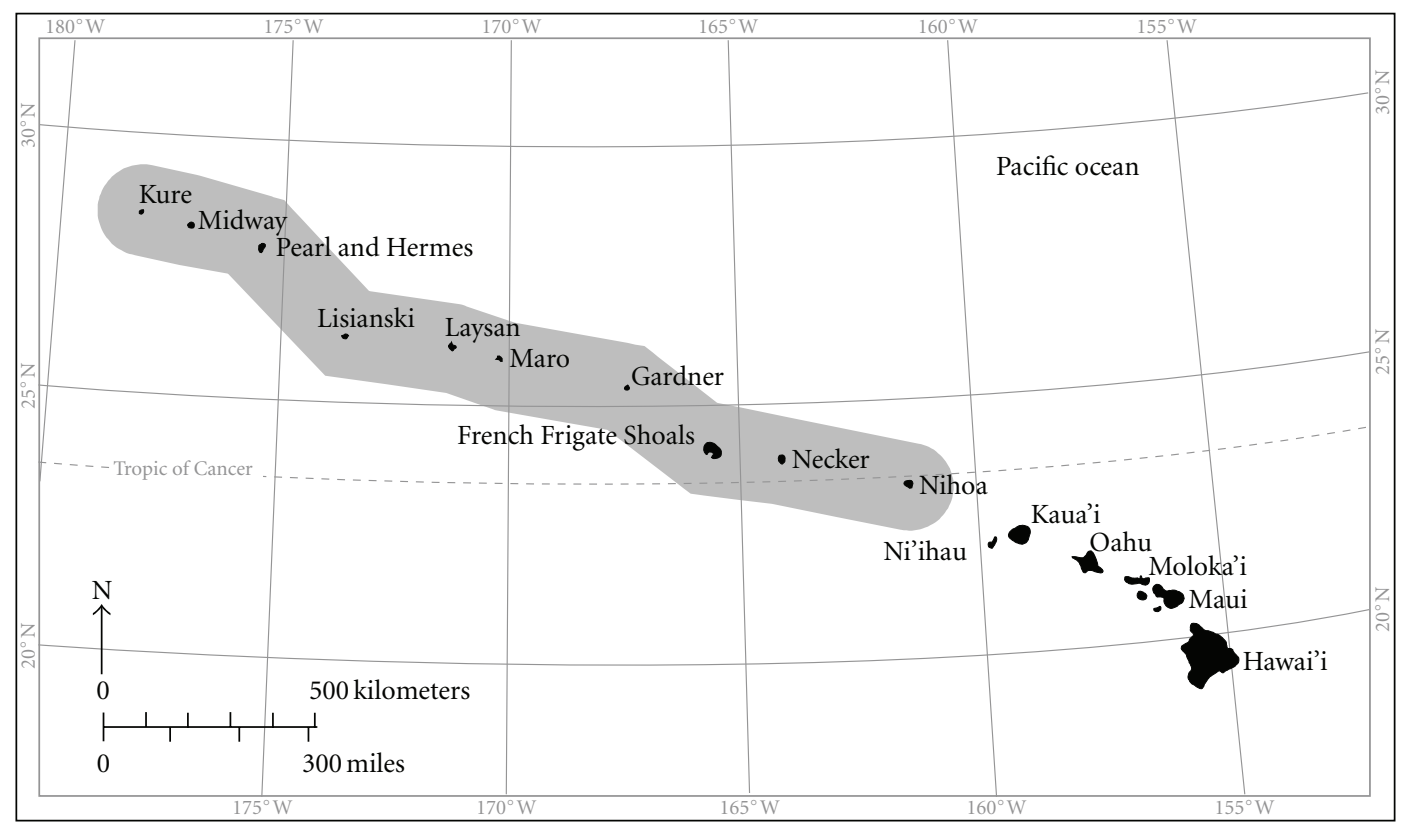

Figure 1: Map of the Hawaiian Archipelago showing major islands, reefs, and atolls. Shaded zone represents boundaries of the Papahānaumokuākea Marine National Monument.

pinnacles, atolls, reefs and submerged banks extending $1,930 \mathrm{~km}$ from Nihoa Rock to Kure Atoll and encompassing an area of $341,360 \mathrm{~km}^{2}$ (Figure 1). These sites are closed to fishing and are characterized by predator-dominated fish assemblages [1]. Here, we review what is currently known about top predator ecology in the PMNM and identify important knowledge gaps that limit our understanding of this ecosystem.

\section{Species Composition and Abundance}

Our knowledge of the species composition and abundance of coral reef-associated predators in the PMNM comes from studies utilizing a variety of fishing and visual census sampling methods, which collectively suggest reef habitats in this region are dominated, both numerically and in biomass, by a small number of predator species, especially the giant trevally (Caranx ignobilis) and the Galapagos shark (Carcharhinus galapagensis) (Figure 2). Giant trevally account for $55 \%$ of all top predators counted by divers in the PMNM (Figure 2) and comprise $71 \%$ of apex predator biomass (equivalent to about $39 \%$ of total fish biomass) in this region [1, 21]. Galapagos sharks are the most abundant elasmobranch, accounting for $9.3 \%$ of all top predators counted during towed-diver surveys and comprising 36 to $53 \%$ of all sharks sampled by towed-diver surveys or longline fishing methods (Figure 2) (see $[21,22]$, J. Dale, unpublished data). Other relatively abundant top predators on PMNM reefs include tiger sharks (Galeocerdo cuvier), grey reef sharks (Carcharhinus amblyrhinchos), whitetip reef sharks (Triaenodon obesus), green jobfish (Aprion virescens), bluefin trevally (Caranx melampygus), amberjack (Seriola spp.), and the endemic Hawaiian grouper (Epinephelus quernus) (see [1, 21-23],
J. Dale, unpublished data) (Figure 2). Less abundant predators documented from PMNM coral reefs include several other carcharhinid sharks, hammerhead sharks, and large jacks (see [21, 22], J. Dale, unpublished data) (Figure 2).

Overall species composition of reef-associated predator assemblages is broadly similar throughout the Hawaiian chain, but there are marked differences in abundance between the PMNM and Main Hawaiian Islands (MHI) [1]. The most notable difference is a general lack of sharks and large teleosts, such as giant trevally, on shallow MHI coral reefs possibly as a result of overfishing [1]. However, recent studies conducted around Hawaii Island indicate giant trevally are still relatively abundant in deeper $(>80 \mathrm{~m}) \mathrm{MHI}$ habitats, suggesting these deeper areas may provide a partial refuge from fishing mortality (C. Meyer, unpublished data). Reef-associated sharks are not targeted by fisheries in the MHI, yet are rarely seen during diver surveys in this region [1]. Although direct population assessments are lacking, several historical, recent, and ongoing studies suggest that MHI coastal shark populations remain robust (e.g., [22, 34-37], J. Dale, unpublished data). Specifically, these studies show similar shark catch rates and sizes in the MHI compared with the NWHI whereas fished populations characteristically yield lower catch rates and catches composed of smaller individuals. In addition, coastal sharks are not sold in local Hawai $i$ fish auctions or markets indicating an absence of any directed shark fishery. Low shark abundance on diver surveys may simply indicate avoidance behavior or a deeper depth distribution of sharks in this area [22, 37]. There are also several notable biogeographic patterns of predator distribution within the Hawaiian chain which may result from different habitat preferences, competitive interactions, or thermal tolerances. For example, grey reef sharks are 


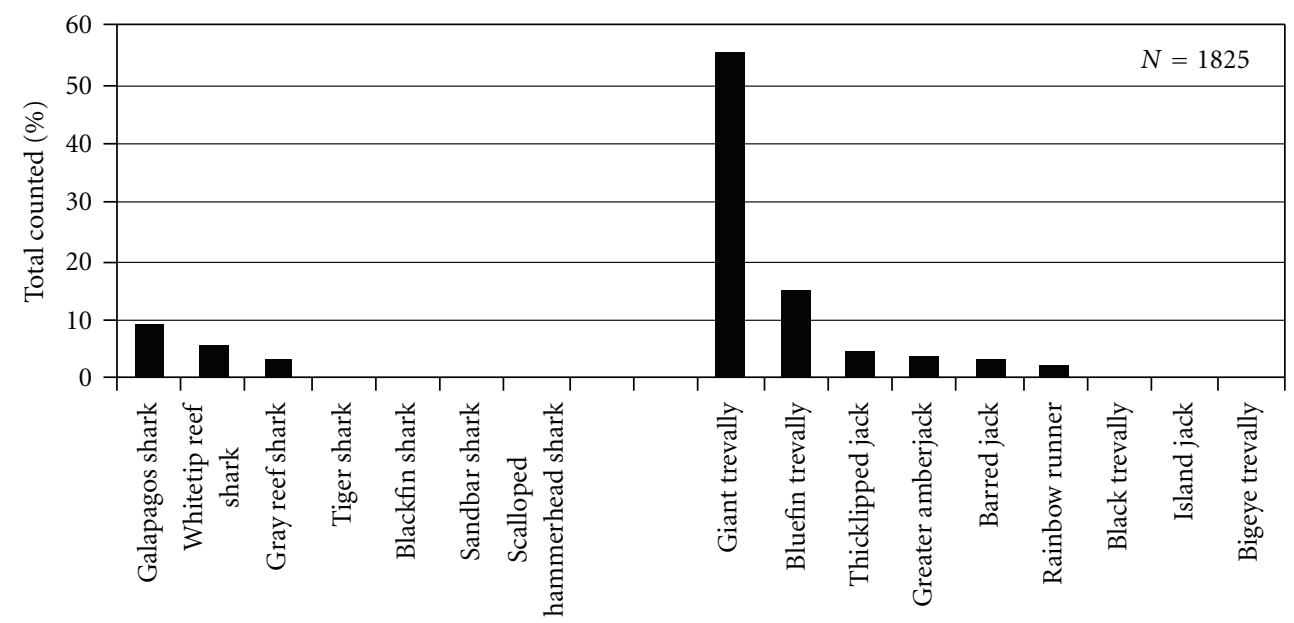

(a)

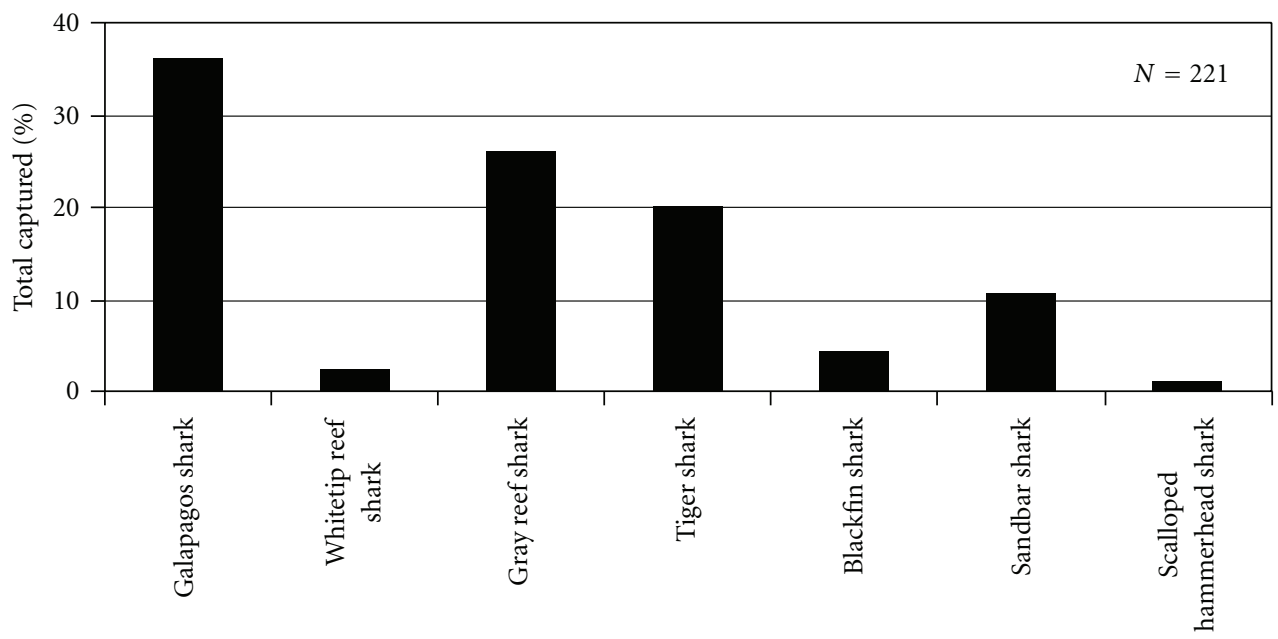

(b)

Figure 2: Species composition of the Papahānaumokuākea Marine National Monument top predator assemblage obtained by towboarding (underwater visual census) $(N=1825)$ and shark longline fishing surveys. Adapted from Holzwarth et al. [21] and J. Dale (unpublished data).

abundant in the PMNM and rare in the MHI whereas the reverse may be true for sandbar sharks [22, 32]. However, sandbar sharks accounted for $10 \%$ of all sharks captured on longlines set at French Frigate Shoals atoll (J. Dale, unpublished data), and we do not yet know how abundant they are at other locations within the PMNM because comparable fishing surveys have not yet been undertaken at these other sites. Grey reef sharks are generally more abundant at atolls than high islands throughout their geographic range, suggesting they are better adapted to, or prefer, atoll habitats [32]. Sandbar and grey reef sharks also have high dietary overlap in locations where they cooccur, suggesting competitive exclusion may play a role in their distributions [22]. Tropical submergence [38] clearly influences the depth distributions of other species including Hawaiian grouper, a heavily-targeted endemic species, along the Hawaiian chain [39]. This species is common in shallow $(<30 \mathrm{~m})$ reef habitats at Kure and Midway Atolls (C. Meyer, pers. obs.) but occurs at deeper depths throughout the rest of the archipelago [40], including atolls as far northwest as Pearl and Hermes Reef (adjacent to Midway Atoll in the Hawaiian chain). Coral reef habitats in the PMNM have remained largely unfished in recent decades, suggesting Hawaiian grouper depth distribution is not simply an artifact of fishing pressure. The whitetip reef shark is rare at the two northern-most atolls but common throughout the rest of the chain [21]. A lack of targeted fisheries for this species in Hawaii suggests their distribution may be influenced by low winter sea temperatures at the northern end of the archipelago.

The PMNM predator assemblage mirrors the high predator abundances seen at other remote, unfished atolls in the Pacific (e.g., [6]), but has a different species composition probably due to broad regional differences in fauna. The diversity of shark species in the PMNM is similar to that of other isolated atolls in the Indo-Pacific where a 

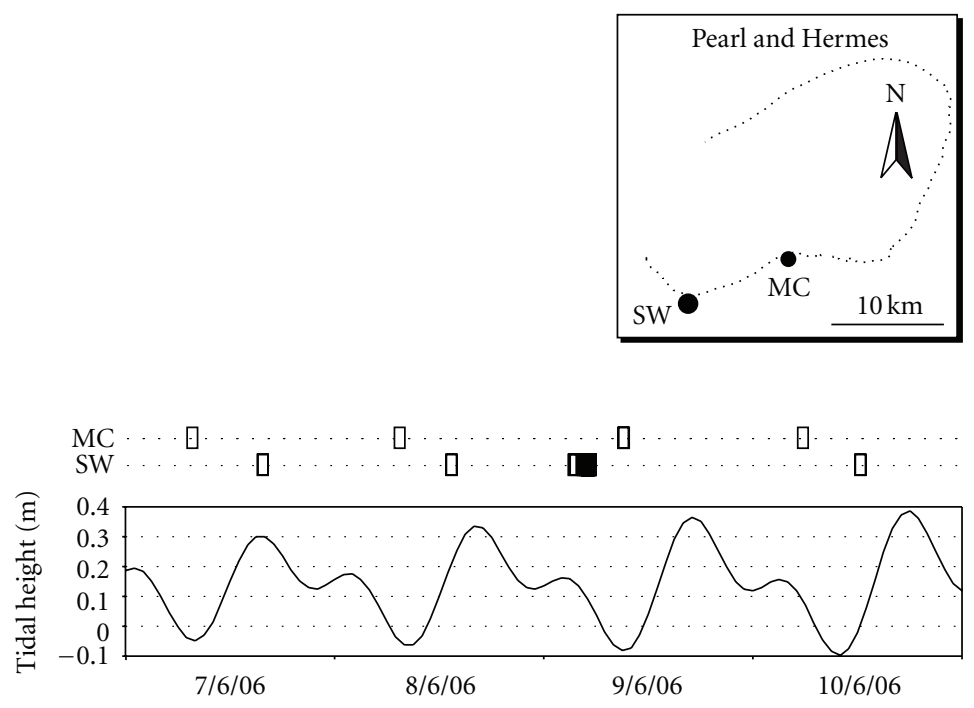

FIgure 3: Tidal rhythmicity in green jobfish movements at Pearl and Hermes Reef (PHR). Top panel: receiver locations (solid circles) on the south side of PHR. Middle panel: detections of a single green jobfish (open rectangles) at PHR over $4 \mathrm{~d}$ in June 2006 . Bottom panel: tidal curves for the $4 \mathrm{~d}$ period. The green jobfish was detected in the vicinity of the main channel (MC) around low tide and moved toward the south west tip of Pearl and Hermes Reef (SW) on the flooding tide. Return migrations from the SW tip to the main channel occurred on the ebbing tide. From Meyer et al. [51].

few species numerically dominate the shark assemblage [5, 41-46]. A lack of blacktip reef sharks (Carcharhinus melanopterus) distinguishes the PMNM shark assemblage from those at many other Indo-Pacific atolls, where this species is abundant $[41,47,48]$. The teleost component of the PMNM predator assemblage is distinguished from those at other remote Indo-Pacific atolls by lower diversity and a general lack of groupers and snappers, especially the twinspot snapper (Lutjanus bohar) which is a numerically dominant teleost predator at many other central Pacific locations (e.g., [5]).

Previous studies of PMNM top predators have quantified relative abundance and/or density (number/biomass per unit area), but there have been few attempts to determine actual population sizes. Very different methods (e.g., diver transect, towed-diver, and fishing surveys) yield broadly similar estimates of top predator relative abundance, but there are clear examples of sampling bias influencing results for some species. For example, tiger sharks are very rarely sighted during visual census surveys but account for up to $20 \%$ of all sharks captured on longlines set in PMNM habitats (see $[1,21,22]$, J. Dale, unpublished data) (Figure 2). In contrast, $30 \%$ of all sharks sighted during towboard surveys are whitetip reef sharks, yet this species accounts for $<3 \%$ of sharks captured on longlines in the PMNM (see [21, 22], J. Dale, unpublished data) (Figure 2). Predator behavior may also have considerable impacts on density estimates derived from visual census surveys. For example, giant trevally are highly attracted to divers in the PMNM but typically flee humans in the MHI (C. Meyer, pers. obs.), potentially leading to divergent, skewed estimates of abundance between the two regions. Giant trevally are also known to form seasonal, lunar spawning aggregations which result in fish from across entire atolls concentrating at a few sites during summer full moons [49]. Such phenomena may bias population density estimates and/or inflate variances of the estimates if visual surveys are carried out during aggregation times. Mark-recapture techniques provide an alternative method for calculating top predator population sizes, but to date, there have been few attempts to apply these methods in the PMNM due to the considerable effort required to obtain sufficient sample sizes for robust estimates of population size. A recent study used mark-recapture to calculate a population size of 668 (95\% CI 289-1720) Galapagos sharks at FFS (J. Dale, unpublished data). This calculation was based on only $4(5.4 \%)$ recaptures of 73 tagged sharks captured during 3 months of intensive shark fishing at this location. However, recent work (see section on movements below) indicates most top predators are site attached to their "home" atolls, and hence they are theoretically suitable candidates for markrecapture estimates derived from closed population models. Top predator population size estimates are a key knowledge gap in our understanding of PMNM ecology. Although logistically challenging to obtain, such empirical estimates would be extremely valuable for validating density estimates produced from visual census surveys and parameterizing ecosystem models (e.g., [50]).

\section{Movement Patterns and Habitat Preferences}

A series of recent electronic tagging studies at PMNM sites suggest individuals of the most abundant species of coral reef top predators are generally site-attached to their "home" island or atoll, but many move extensively within atolls during diel, tidal, lunar, and seasonal migrations [36, 49, 5153] (Figure 3). For example, giant trevally spend most of the year in relatively small (maximum linear dimension $=$ $5 \mathrm{~km}$ ) home ranges, where they exhibit clear diel habitat 


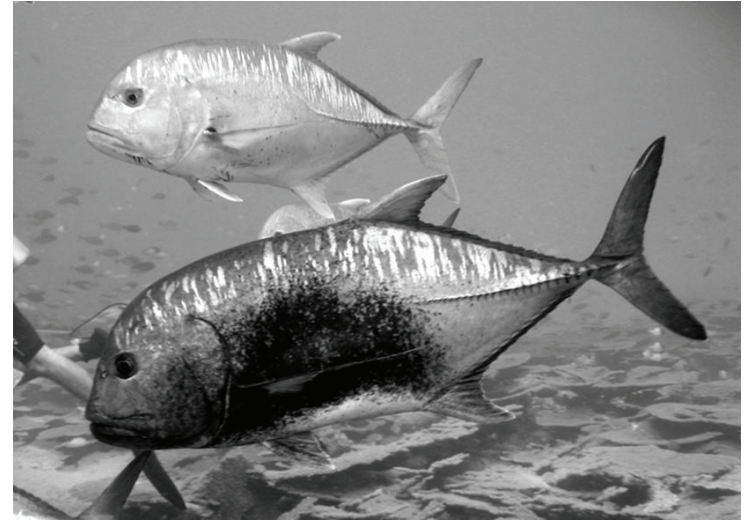

(a)

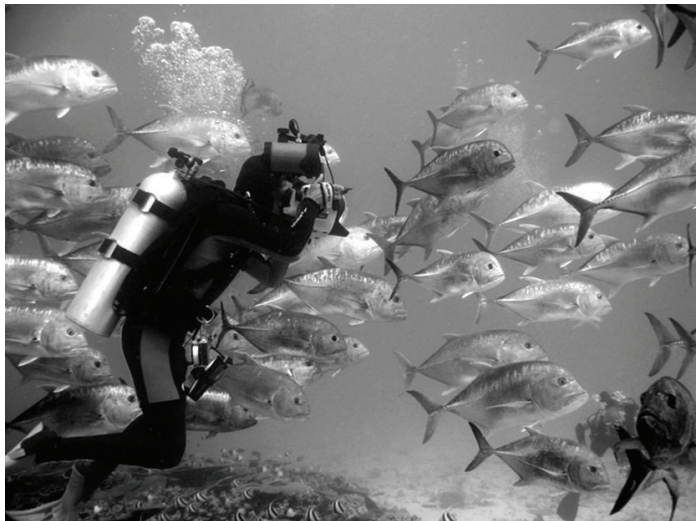

(b)

Figure 4: (a) Color dimorphism in giant trevally from school at Rapture Reef. (b) Giant trevally school at Rapture Reef (FFS Atoll), May 23 2006. Photographs reproduced by permission of Jill Zamzow. From Meyer et al. [49].

shifts (see [49], C. Meyer, unpublished data), but migrate up to $40 \mathrm{~km}$ to spawning aggregation sites during summer full moons (see [49], C. Meyer, unpublished data) (Figure 4). Green jobfish are also seasonally site attached to core activity areas of up to $12 \mathrm{~km}$ in length, and range up to $19 \mathrm{~km}$ across atolls [51]. Within their core areas, green jobfish exhibit diel and tidal habitat shifts (Figure 3 ), with the latter resulting in round trips of up to $24 \mathrm{~km}$ in $24 \mathrm{~h}$ [51]. Galapagos sharks also appear to be primarily resident at "home" atolls, with adults moving extensively throughout atolls and juveniles exhibiting diel migrations between fore reef and reef flat habitats $[52,53]$. Tiger sharks are the notable exception to the atoll-residency pattern. Although some individuals are detected at their home atoll year round, others routinely swim hundreds or thousands of $\mathrm{km}$ along the Hawaiian chain or out into open ocean [49, 53-55] (Figure 5).

Data from diver transect and towed-diver visual surveys and fishing and tagging studies show that the most common top predators occur throughout all major atoll and bank habitats, but some species exhibit preferences for particular habitat types or locations (see [21, 23, 49, 51-53], J. Dale, unpublished data). Indeed, electronic tagging studies show individual predators often utilize multiple different habitats at PMNM atolls, but are detected most frequently in just a few [49, 51-53]. Collectively, these studies suggest large predators in the PMNM, as elsewhere in the central Pacific [56], are generally most abundant in atoll fore reef habitats and least abundant in shallow $(<3 \mathrm{~m})$ lagoon and back reef habitats (see [21], J. Dale, unpublished data). However, electronic tagging data also indicate many tiger sharks and some Galapagos sharks actively seek out shallow habitats around small sandy islets, presumably because of abundant, large prey (birds, turtles, and seals) in these locations (see $[52,53]$ - see also diet section below), and core home ranges of some giant trevally individuals are located in these shallow areas [49]. Top predators also select specific habitats for biologically important activities such as spawning. For example, during summer full moons, giant trevally from across FFS congregate in fore reef habitat on the south side of the atoll [49] (Figure 4). Few data are available on vertical movements of top predators in the PMNM but limited satellite tagging in this region has shown both Galapagos and tiger sharks primarily use the mixed layer $(<100 \mathrm{~m}$ depth) and make occasional deeper dives through the thermocline down to $680 \mathrm{~m}$ [53] (Figure 6).

In many cases, movement data from teleost predators tagged in the PMNM are among the first available for those species, precluding comparisons with other areas. Overall, PMNM teleost predators exhibit rhythmic patterns of movement that are broadly similar to, but wider-ranging than, other coral reef fishes (e.g., [57]), which has important implications for Marine Protected Area (MPA) design (e.g., $[49,51])$. Recent studies suggest giant trevally movement patterns in the MHI closely resemble those documented in the PMNM (C. Meyer, unpublished data), and this species is known to form lunar spawning aggregations at predictable locations in other areas of the Pacific [58-62]. Little is known about Galapagos shark movements in any part of their geographic range, but the few data available suggest broadly similar patterns of site fidelity and vertical movement to those observed in the PMNM. A Galapagos shark tagged off Bermuda was recaptured $2,859 \mathrm{~km}$ away off the coast of Suriname, but most recaptures (12 of 14) were within $100 \mathrm{~km}$ of the original capture sites [63]. In the MHI, Galapagos shark abundance at cage diving ecotourism sites has clear, annual cycles, indicating seasonal movements to and from this location [51]. Galapagos sharks in Hawaii have been captured at depths of 0 to $286 \mathrm{~m}$ although most were caught between 30 and $50 \mathrm{~m}$ [30]. Tiger shark movements within the PMNM are also similar to those documented elsewhere, showing these sharks occupy large home ranges within which they employ specific localized patterns of movement and habitat use [25, 36, 54, 63] (Figure 5). Seasonal movements may occur at the latitudinal extremes of their distribution $[64,65]$. Active tracking of tiger sharks equipped with acoustic transmitters off Oahu, Hawai'i revealed orientation 


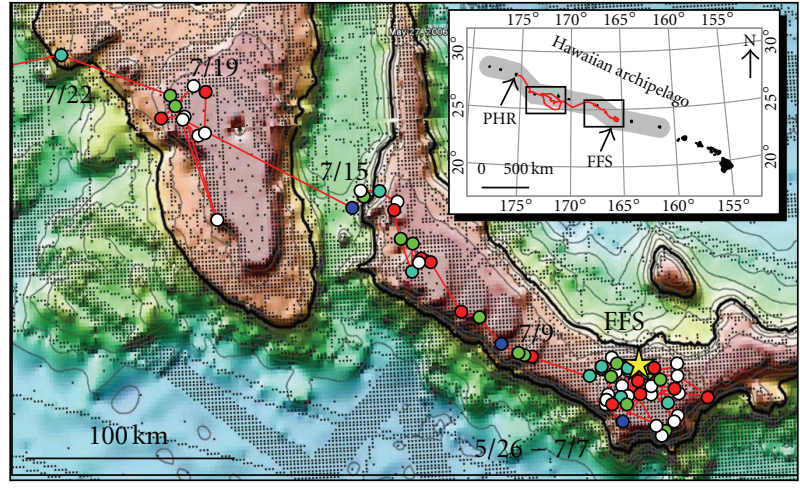

(a)

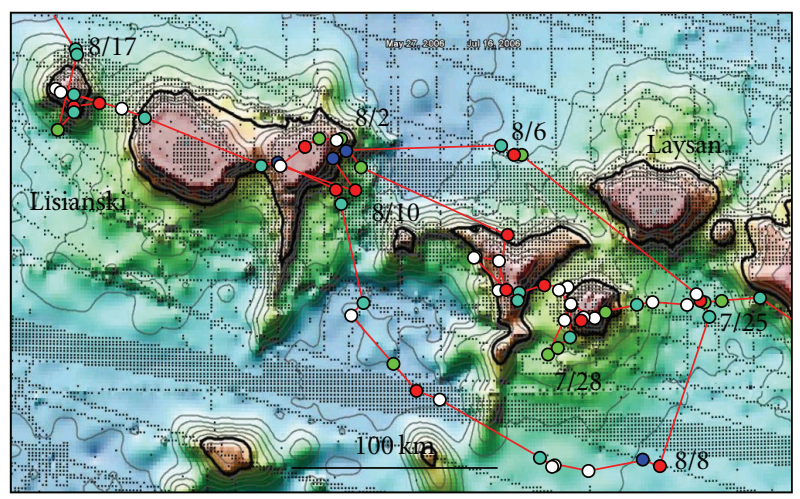

Location quality

- 3

- 0

○ 2

- A-B

秥 Release point

(b)

FIGURE 5: Inset: Overview of a tiger shark (TS5) SPOT track (red line) from French Frigate Shoals (FFS) to Pearl and Hermes Reef (PHR) within the Papahānaumokuākea Marine National Monument (shaded area). Boxes indicate regions of track shown in detail in top and bottom panels. Top panel: concentration of SPOT detections at FFS between 5/26/06 and 7/7/06, and route taken after departure from FFS on 7/8/06. Bottom panel: detail of SPOT detections associated with submerged banks and seamounts surrounding Lisianski and Laysan islands. From Meyer et al. [53].

to the bottom in depths $<300 \mathrm{~m}$ and to the mixed layer (0$80 \mathrm{~m}$ ) in deeper waters with occasional brief dives as deep as $335 \mathrm{~m}$ [54].

Many sharks and teleosts use well-defined nursery habitats (e.g., $[66,67])$, but relatively little is known about juvenile top predator habitat use in the PMNM. Among teleosts, young-of-the-year Hawaiian grouper inhabit turf algaedominated deep-bank terraces whereas giant and bluefin trevally recruit to the shoreline edge of protected sandy areas adjacent to reefs [68]. Specific nursery habitats have not yet been identified for any shark species in the PMNM, but fishing surveys capture immature Galapagos, tiger and grey reef sharks (see [22, 30, 32], J. Dale, unpublished data), and aggregations of immature Galapagos sharks can be seen predictably at several locations within the PMNM (Figure 7).
Although recent studies have provided important insights into long-term movement and habitat-use patterns of coral reef predators in the PMNM, significant knowledge gaps remain. We still lack any empirical movement data for several relatively abundant predator species in this region, including amberjack and whitetip reef sharks, and we have no fine-scale habitat use or depth data for most species. The importance of juvenile recruitment to adult stocks underlies the need to identify key nursery areas for both sharks and large teleosts. Future fishing surveys could utilize gear configurations specifically targeting juveniles to address this knowledge gap. More fundamentally, we understand few of the specific drivers of the observed predator movements and habitat use. Presumably, predators visit specific locations to engage in biologically significant behaviors of foraging and reproduction, and site selection is driven by biological and physical characteristics of those sites. The few cases in which we can tie movement patterns directly to specific biological activities (tiger shark foraging on fledging sea birds, Galapagos shark predation on Hawaiian monk seal pups, giant trevally spawning aggregations) all involve visual confirmation of the behavior (Figure 8). However, in most cases, ecologically important behaviors occur completely unseen by humans. Fortunately, a new generation of "ecology tags" promises to provide important new insight into the ecology of marine animals. These devices include accelerometer dataloggers which provide high-resolution spatial tracks and biomechanical data on swimming activity, stomach tags which measure changes in stomach $\mathrm{pH}$ to identify feeding events, and hydrophone tags which record biologically significant sounds and interanimal interactions (e.g., [69-72]). Future studies could shed light on the frequency and locations of feeding and mating by combining instruments which tell us about spatial behavior and physical oceanography with this new generation of "ecology tags".

\section{Trophic Ecology}

Top predators in the PMNM consume a wide variety of prey including invertebrates, fishes, marine mammals, turtles, and sea birds. Giant trevally are the most abundant predator in the PMNM, and diet studies suggest their foraging activities significantly impact lower trophic levels [24]. Their diet is dominated by reef fishes and invertebrates, including octopus and adult lobsters, but also includes pelagic species such as squid and mackerel scad (Decapterus macarellus). Overall diet indicates giant trevally forage primarily in shallow-water reef habitats but also feed in open water [24, 73]. Their diet contains a large amount of nocturnally active prey indicating a significant amount of nighttime feeding by this species [24]. Dietary overlap between giant and bluefin trevally (another abundant reef-associated jack) is moderate, with shallow-water reef fishes and small crustaceans, respectively, making larger and smaller contributions to bluefin trevally diet [24]. A low incidence of nocturnally active prey items and the absence of pelagic species suggest bluefin trevally are primarily diurnal foragers in shallow-water reef habitats. Differences in foraging strategies and the ability of large adult giant trevally to feed on larger prey (e.g., adult lobsters) may 


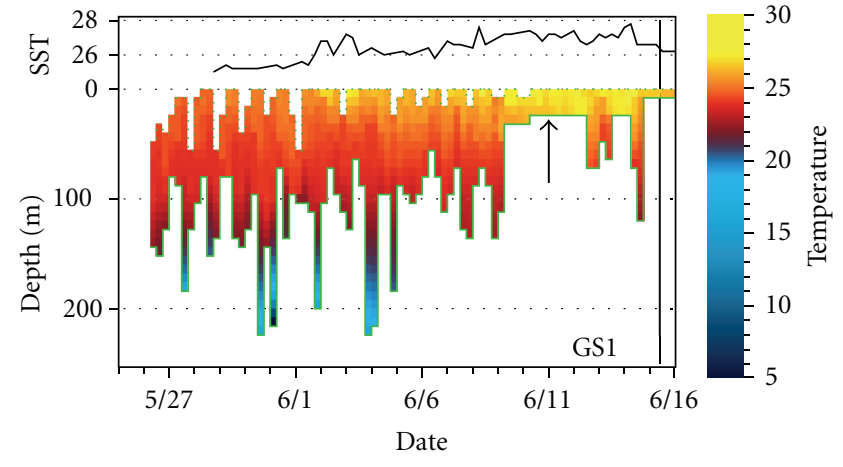

(a)

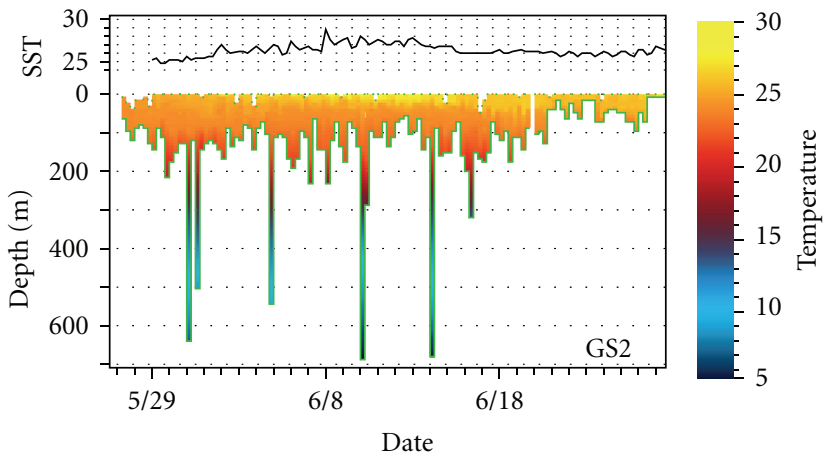

(b)

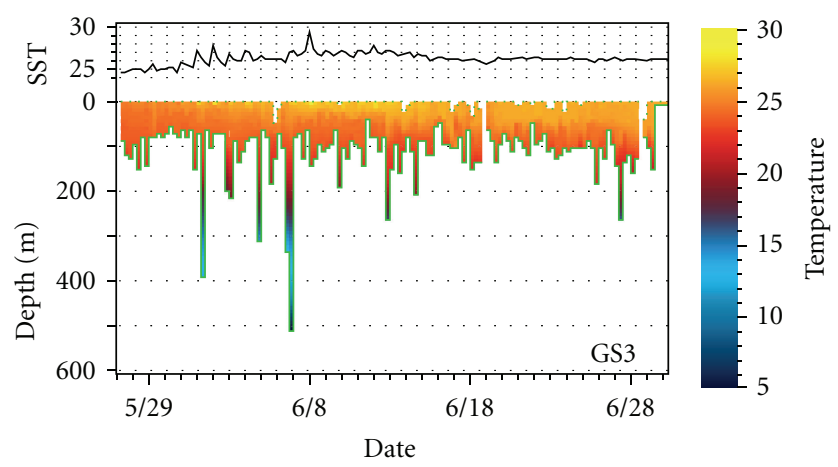

(c)

Figure 6: Popup Satellite Archival Tag (PAT) depth-temperature histograms (6h bins) and Sea Surface Temperature (SST) plots for three Galapagos sharks captured at French Frigate Shoals (FFS) in May 2006. Note 3 day period spent swimming shallower than $30 \mathrm{~m}$ depth by GS1 (Arrow). From Meyer et al. [53].

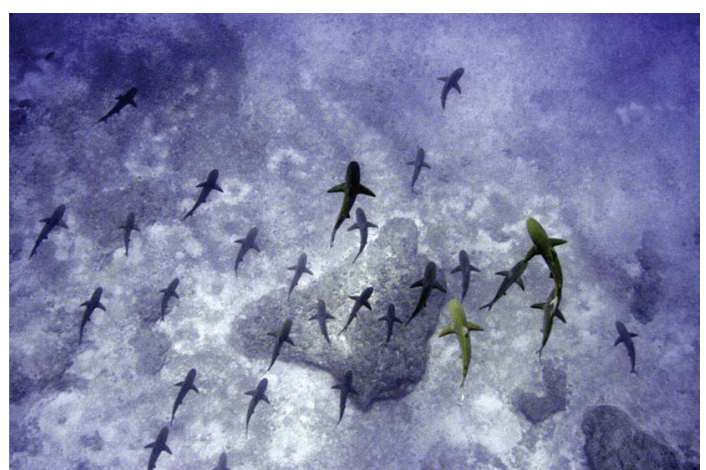

FIgURE 7: Aggregation of juvenile Galapagos sharks at Midway Atoll. Photograph reproduced by permission of Kevin Flanagan.

reduce niche overlap between these two sympatric species $[24,73]$.

Other abundant teleost predators in the PMNM include green jobfish, Hawaiian grouper, and amberjack. Although these commonly occur in shallow-water $(0-40 \mathrm{~m})$ areas, existing diet data are garnered from individuals captured in deep-water PMNM habitats (55-250 m) [74-78]. All three species are primarily piscivorous although crustaceans contribute significantly to the diet of Hawaiian grouper.

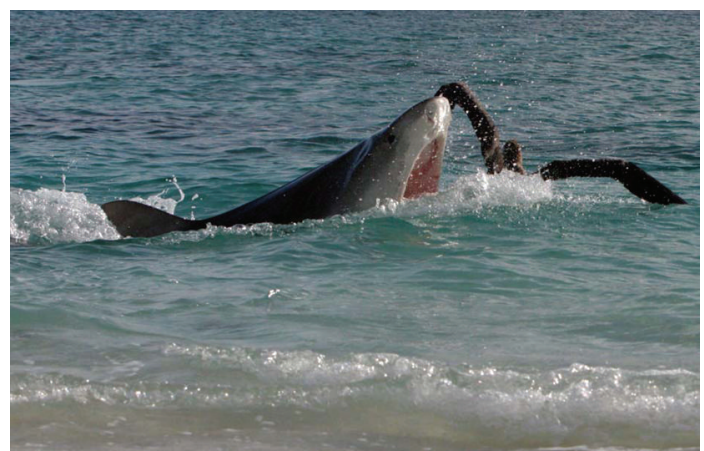

FIGURE 8: Tiger shark foraging on fledging blackfoot albatross at East Island, French Frigate Shoals. Photo A. Rivera.

Hawaiian grouper and amberjack are primarily benthic carnivores, but larger amberjacks consume significant amounts of mid-water prey. Consumption of larval and mid-water prey also suggests pelagic foraging by green jobfish. Green jobfish are diurnal predators whereas Hawaiian grouper appear to feed nocturnally or during crepuscular hours, and the timing of amberjack feeding is unknown.

Our knowledge of shark diets in both the MHI and PMNM comes from a series of historical fishing surveys [28, $30,32,34,79$ ], which collectively suggest sharks have broadly similar foraging habits throughout the Hawaiian archipelago. 


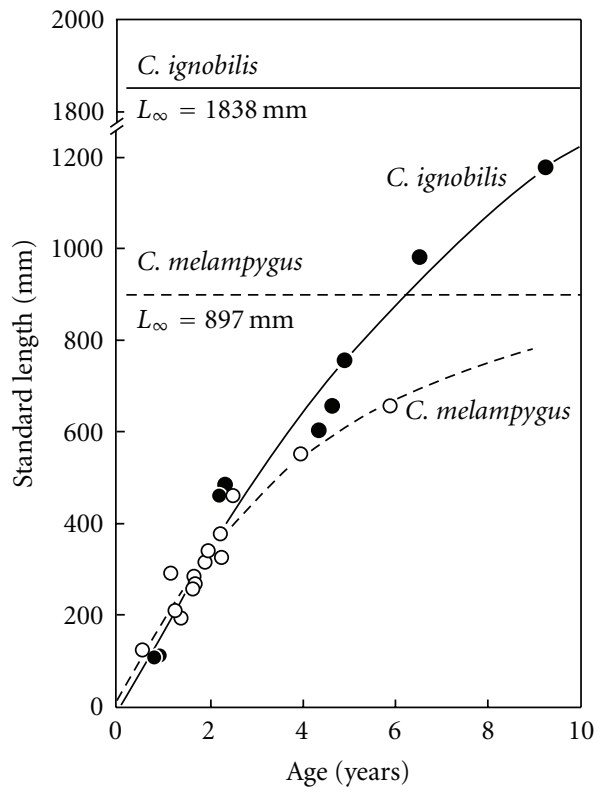

Figure 9: Growth data and von Bertalanffy growth curves derived for Caranx melampygus and Caranx ignobilis. Age was estimated by counting daily growth increments of otoliths. From Sudekum et al. [24].

Overall, shark diets are dominated by teleosts, but also include significant amounts of cephalopods and crustaceans. Clear ontogenetic shifts in diet are evident, with decreases in the contribution of teleosts accompanied by increases in prey diversity with increasing shark size. Dietary overlap between shark species is generally low whereas intraspecific overlap along the Hawaiian chain is high. Notable exceptions to these general trends include high dietary overlap between sandbar sharks and grey reef sharks (species which show opposite patterns of geographic abundance along the Hawaiian chain $[22,32])$, and between large Galapagos and tiger sharks [22], both of which consume large prey such as elasmobranchs, sea birds, turtles, and marine mammals. Tiger sharks diets also contain more of these large prey in the PMNM than in the MHI [79], presumably reflecting differences in prey availability between these two regions. The PMNM contains important breeding grounds for sea birds, turtles, and the critically endangered Hawaiian monk seal (Monachus schauinslandi), creating high densities of potential shark prey, particularly during the summer months. Tiger sharks can be seen foraging seasonally on fledging albatross (primarily blackfoot albatross, Phoebastria nigripes [52]) (Figure 8) and are also known to prey on monk seals [28]. Galapagos sharks are occasionally witnessed preying on monk seal pups and are suspected of additional, unseen predation at pupping beaches [80].

Several key knowledge gaps remain in our understanding of trophic ecology of top predators in the PMNM. For example, we lack basic diet data from shallow-water coral reef habitats for several abundant predators such as green jobfish, Hawaiian grouper, and amberjack. Although we know what many sharks and fishes eat, we still know little about when they feed or how much they consume each day. Bioenergetic models have been used to estimate prey consumption by sharks and trevally $[24,28]$ at French Frigate Shoals, but have lacked robust empirical data for key input parameters such as population size and metabolic rates [82], greatly increasing uncertainty of the results. For example, model estimates suggest giant and bluefin trevally consume more than 30,000 $\mathrm{mt}$ of prey per year at FFS, exceeding the estimated combined consumption of tiger, Galapagos, and grey reef sharks at the same atoll by a factor of 40 . We need to understand the transfer of energy between trophic levels in order to comprehend how these ecosystems function, hence additional empirical data on consumption rates are required. Emergent technologies such as $\mathrm{pH}$ and acceleration tags $[70,83]$ show promise for providing these data. In blacktip reef sharks, prey consumption rapidly increases stomach $\mathrm{pH}$ and the amount of prey consumed is linearly related to the magnitude of $\mathrm{pH}$ changes, providing the potential for direct estimates of the timing and frequency of feeding as well as the daily ration. In captive scalloped hammerhead sharks (Sphyrna lewini), body acceleration was linearly related to metabolic rates, providing the potential to quantify these rates for free-swimming sharks [83]. These methods offer promising tools for validating existing estimates of prey consumption in the field.

\section{Age, Growth, and Reproduction}

The PMNM top predator assemblage is characterized by large-bodied, long-lived sharks, and jacks. Maximum size reached by adult predators ranges among species from $<1$ to $>4 \mathrm{~m}$, and growth rates also vary interspecifically [24, 28]. Maximum observed age estimates range from 6 years for bluefin trevally [24] to 22 years for tiger sharks [28], with reproductive size reached in 2 to 10 years $[24,28]$. Predatory teleosts reproduce at an earlier age and reach smaller maximum sizes than sharks in the PMNM. The timing of spawning/birthing for top predators is highly seasonal, generally occurring in the spring and summer months $[24,30,32]$.

Giant trevally grow slightly faster and reach a larger maximum size than the closely related bluefin trevally (Figure 8), but the latter reproduce at an earlier age and smaller size [24] (Table 1). Based on the von Bertalanffy growth coefficient $(K)$, giant and bluefin trevally attain $95 \%$ of their theoretical maximum sizes at 31 and 15 years, respectively, but these are likely only minimum estimates as maximum observed ages were 9 and 6 years (Table 1, Figure 9). Bluefin trevally are highly fecund ( $>4$ million mature ova in the ovary of a $6.5 \mathrm{~kg}$ female), with an exponential increase in the number of eggs produced with size [24]. Spawning activity peaks for both giant and bluefin trevally between May and August [24]. Age, growth, and reproductive data are not available for other common teleost predators in the PMNM, but green jobfish in the MHI reach sexual maturity between $0.45-0.5 \mathrm{~m}$ Fork Length (FL) (Table 1) and have a protracted spawning season between May and October [26]. Green jobfish on the Great Barrier Reef (GBR) reach maximum ages of 16 years and a theoretical maximum size of $0.7 \mathrm{~m} \mathrm{FL} \mathrm{[27]} \mathrm{(Table} \mathrm{1).}$ 
TABle 1: Summary of life history studies conducted on top predators in the Hawaiian archipelago. SL: Standard Length, FL: Fork Length, and TL: Total Length.

\begin{tabular}{|c|c|c|c|c|c|c|c|}
\hline Species & Max size & Max growth rate & Max age & Size at maturity & Age at maturity & Litter size & Source \\
\hline Bluefin trevally & $0.9 \mathrm{~m} \mathrm{SL}$ & $18 \mathrm{~cm} / \mathrm{yr}$ & 15 & $0.35 \mathrm{~m} \mathrm{SL}$ & $2 y$ & - & {$[24]$} \\
\hline Giant trevally & $1.8 \mathrm{~m} \mathrm{SL}$ & $19 \mathrm{~cm} / \mathrm{yr}$ & 31 & $0.6 \mathrm{~m} \mathrm{SL}$ & $3.5 \mathrm{y}$ & - & {$[25]$} \\
\hline Green jobfish & $0.7 \mathrm{~m} \mathrm{FL}$ & - & 16 & $0.3-0.5 \mathrm{~m} \mathrm{FL}$ & - & - & {$[26,27]$} \\
\hline Tiger shark & $4.4 \mathrm{~m} \mathrm{TL}$ & $40 \mathrm{~kg} / \mathrm{yr}$ & 28 & $290-345 \mathrm{~cm} \mathrm{TL}$ & $10 y$ & 32.6 & {$[28,29]$} \\
\hline Galapagos shark & $2.9 \mathrm{~m} \mathrm{TL}$ & $14 \mathrm{~kg} / \mathrm{yr}$ & 24 & $205-245 \mathrm{~cm} \mathrm{TL}$ & $10 \mathrm{y}$ & 8.7 & {$[28,30,31]$} \\
\hline Grey reef shark & $2.2 \mathrm{~m} \mathrm{TL}$ & $5 \mathrm{~kg} / \mathrm{yr}$ & 18 & $120-140 \mathrm{~cm} \mathrm{TL}$ & $6 y$ & 4.1 & {$[28,32,33]$} \\
\hline
\end{tabular}

Size of sexual maturity for green jobfish on the GBR was not determined, but all sampled fishes were mature at $0.3 \mathrm{~m}$ FL.

Among PMNM sharks, tiger sharks are the largest and fastest growing followed by Galapagos and grey reef sharks (see $[28,33,81]$, C. Meyer, unpublished data) (Table 1, Figure 10). Tiger sharks also reproduce at a larger minimum size and have a higher maximum age than these other species [28-33, 81] (Table 1). Age at first reproduction for female gray reef sharks is 6 years, and 10 years for both Galapagos and tiger sharks [28]. Tiger sharks have larger mean litter sizes than both Galapagos and grey reef sharks $[29,30,32]$ (Table 1). Mating occurs in the winter and spring with parturition in the spring and summer following 12 (Galapagos and grey reef) or 16 (tiger) month gestation periods [29, 30, 32]. Reproduction is thought to occur every 2-3 years for these species [29, 30,32]. We lack age, growth, and reproductive data for other common sharks in the PMNM.

Several important caveats limit our understanding of top predator age, growth and reproduction in the PMNM. For example, the few studies available are mostly based on relatively small sample sizes. For age and growth, the periodicity of band formation in otoliths (teleosts) or vertebrae (sharks) has only been partially validated in two teleost species (giant and bluefin trevally [24]), and longevity estimates for these predators have never been confirmed. Daily growth increment validation was conducted on fishes smaller than the maximum observed sizes, and increment formation in the otoliths of larger individuals may be slower [85], leading to underestimates of age and overestimates of growth rate. Reproductive traits such as gestation length and reproductive periodicity are only preliminary estimates, and additional data are required to confirm them. Additional, similar studies could provide age, growth, and reproductive data for other common species but would require several hundred individuals to be sacrificed. Mark recapture studies provide an alternative, nonlethal method for calculating growth, and could also provide much needed population size estimates, but require considerable effort to obtain adequate sample sizes. Sexual segregation is prominent for sharks in the PMNM, and in other locations, this phenomenon has been linked to reproductive behavior [86,87], yet little is known of the specific environmental and behavioral factors driving sexual segregation in the PMNM. Identification of spawning and mating sites could provide insight into the habitat requirements for such behaviors, essential information for

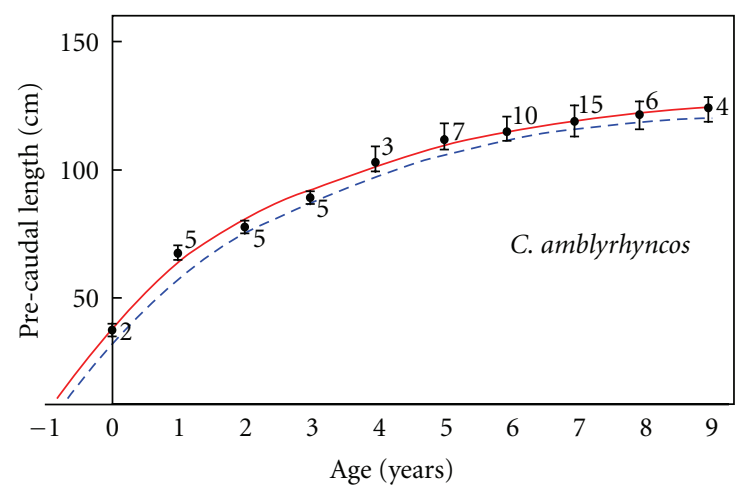

(a)

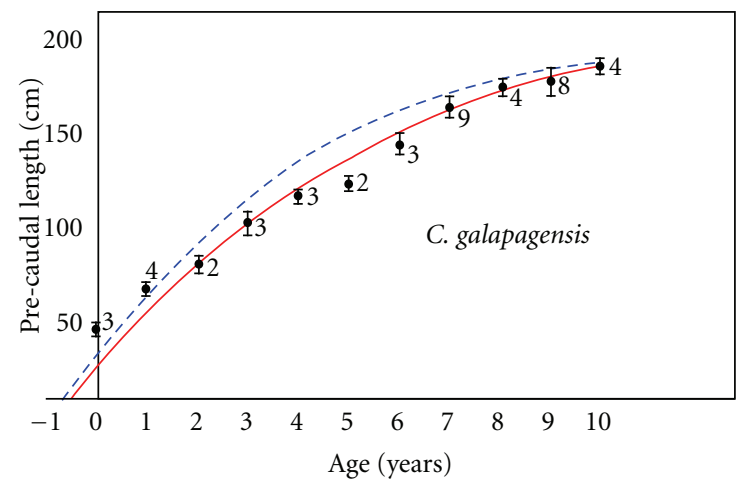

(b)

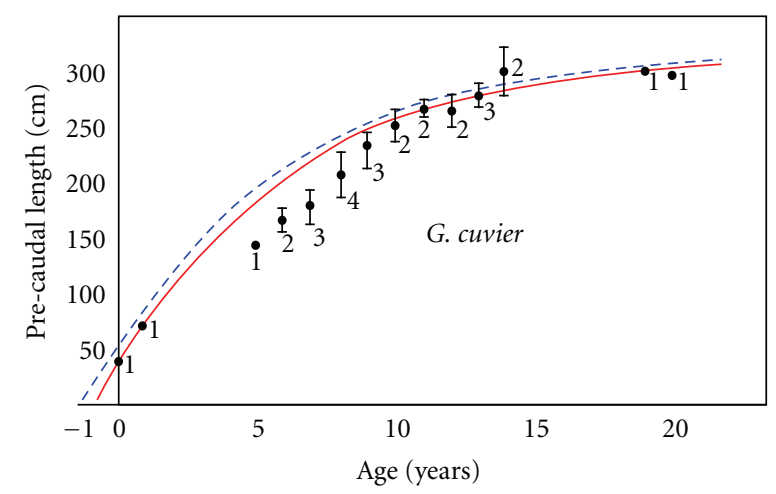

(c)

Figure 10: Von Bertalanffy growth curves calculated from the vertebral age determination data (solid line)—with mean length of age class indicated by dots, the range by bars, and the sample size by numbers-and from a length-frequency analysis of data from Tester [81] (dashed line). From DeCrosta et al. [28]. 


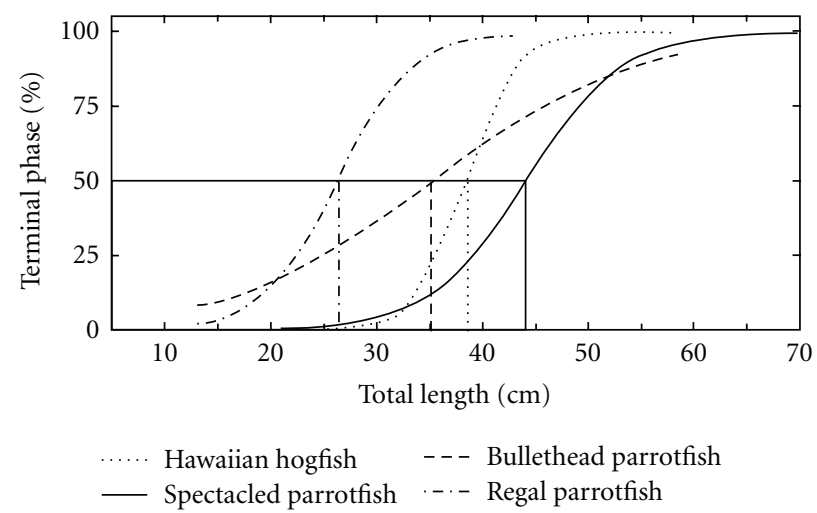

(a) Pearl and Hermes

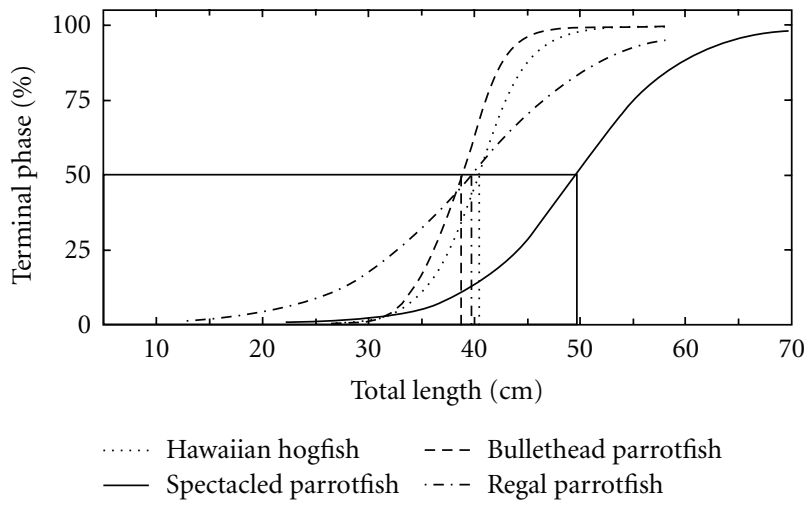

(b) Kure

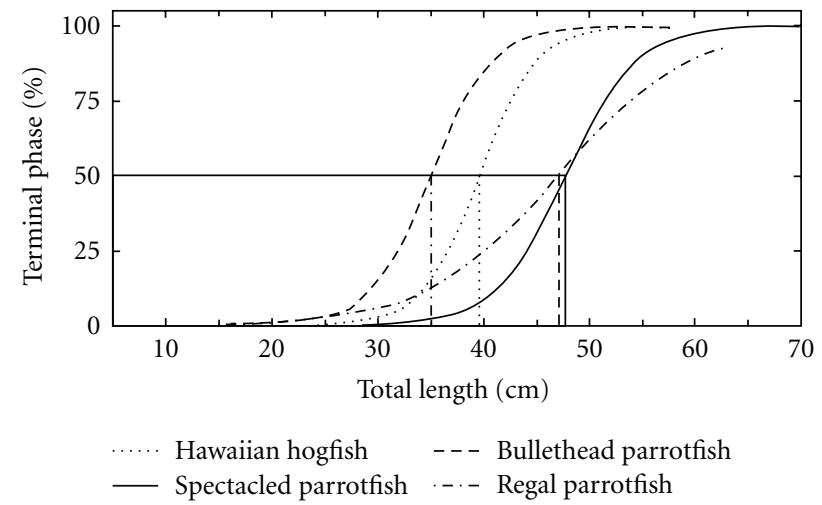

(c) Midway

FIGURE 11: Scatterplots and logistic spline curves (predicted fits) of percentage terminal phase (for all individuals observed, both initial and terminal phases) by $5 \mathrm{~cm}$ total length class, for each of 4 major species of labroids ( 1 labrid plus 3 scarids), at Pearl and Hermes, Kure, and Midway atolls in the NW Hawaiian Islands during September to October 2000 and 2002. Vertical lines indicate estimated body length at which $50 \%$ of individuals are terminal phase. From DeMartini et al. [84].

the design of MPAs implemented to protect highly vulnerable seasonal aggregations [3].

\section{Ecological Interactions}

The predator-dominated coral reefs of the PMNM [1] provide a rare opportunity to investigate the impacts of top predators on ecosystem dynamics, and recent empirical studies suggest predation pressure influences size composition, life-history characteristics, distribution, and abundance of prey species $[84,88,89]$. For example, size at sex change and mean body size of protogynous labroids are inversely related to giant trevally densities at PMNM atolls [84] (Figure 11). Intra-atoll distribution and abundance of prey fishes may also be influenced by predation pressure. An inverse relationship between abundances of top predators and small carnivores in barrier and patch reef habitats may result from small-bodied prey utilizing patch reefs (which have higher densities of shelter holes) as refuge sites from predation (see [21, 68, 88, 89], J. Dale, unpublished data). Similarly, top predators on low-relief, submerged banks in the PMNM may restrict movements of prey fishes away from sheltering sites, possibly reducing prey foraging and growth rates [23]. Theoretical modeling also suggests significant impacts of top predators on PMNM ecosystem dynamics. For example, models of the French Frigate Shoals ecosystem predict removal of tiger sharks would cause system-wide changes in abundance of a variety of taxa, including those not preyed upon by tiger sharks [90]. Such results highlight the potential importance of indirect effects of top predators on ecosystem function.

Although the effects of predation on lower trophic levels are fairly well documented [23, 84, 88, 89], the effects of inter-specific interactions between top predators are less well understood. We do know predatory fishes and sharks may be an important source of interference competition for critically endangered Hawaiian monk seals in the PMNM. Sealborne video cameras show giant trevally, bluefin trevally, amberjacks, green jobfish, and reef sharks swimming in close association with monk seals, and competing for prey items flushed from cover by the foraging seals [91]. However, seals still have their greatest foraging success in the presence of these competitors, suggesting benefits of feeding in prey-rich patches may outweigh costs of interference competition [91]. New technologies such as hydrophone tags, which record biologically significant sounds and inter-animal interactions [72], could further clarify the nature and importance of inter-specific competition between top predators. 
Relatively little is known about the ecological impacts of top predators in the MHI and most other Indo-Pacific locations, due to the generally low abundance of top predators on shallow coral reefs in areas impacted by humans [1]. The few data available suggest top predators exert similar ecological impacts on shallow-water coral reef ecosystems across a wide geographic area. For example, mean size at sex change for parrotfishes (Scaridae) increases with decreasing densities of top predators in the Northern Line Islands, where the abundance and trophic structure of fishes parallel those of the PMNM (i.e., both have predator-dominated fish faunas) $[5,84]$. In the MHI, distributions of smaller sharks may be driven partly by predation and behaviorally mediated interactions [22, 37]. For example, young-of-theyear scalloped hammerhead sharks aggregate in turbid bays and estuaries, presumably to avoid predation pressure from larger sharks [92]. MHI sandbar shark abundance is inversely related to abundances of larger tiger and Galapagos sharks which prey on sandbar sharks and may also exclude them through competitive dominance [22, 37]. In Australia, tiger sharks exclude bottlenose dolphins (Tursiops aduncus) from productive seagrass foraging habitats, potentially decreasing dolphin fitness [93].

To date, our understanding of the ecological role of top predators in coral reef ecosystems is based largely on correlative studies (e.g., giant trevally density versus size at sex change of labroids $[5,84]$ ), but manipulative experiments are required to definitively demonstrate causation. The PMNM provides ideal environments for conducting manipulative experiments without the confounding effects of anthropogenic influences. Such experiments would greatly increase our understanding of the specific biological and physical factors driving observed relationships.

\section{Conclusions}

Limitations inherent in single species management plans have generated burgeoning interest in ecosystem-based management [94]. This approach requires a thorough understanding of ecosystem processes including species composition, abundance, distribution, spatial utilization, and lifehistory characteristics, as well as trophic relationships among constituent organisms. As one of the few remaining nearpristine coral reef ecosystems $[1,95]$, the PMNM provides a rare opportunity to study ecosystem function and processes free from human disturbance. Top predator studies to date indicate strong top-down control on coral reef fish assemblages in the PMNM. These effects are most clearly evident for giant trevally which structure prey size, distribution, and habitat use, as well as influence reproductive and growth characteristics of prey on shallow-water coral reefs. Large sharks are a significant source of predation on endangered species such as the Hawaiian monk seal, blackfoot albatross, and green sea turtle (Chelonia mydas). Removal of top predators would theoretically lead to large-scale trophic cascades suggesting ecosystem processes may be most impacted by predators through indirect effects of predation $[19,90]$.

The wide-ranging behavior of most top predators has important implications for management of these species.
Large MPAs (i.e., entire atolls, islands, or banks) would be required for complete protection of giant trevally, green jobfish, and most shark populations. MPAs of this scale would be effective when preservation of entire coral reef ecosystems is the management objective, but unrealistic in populated areas due to resistance from stakeholders [9698]. In fished areas such as the MHI, alternative strategies need to be evaluated for the management of top predator populations. Protecting sites of spawning activity is of particular importance, as large spawning aggregations are highly susceptible to rapid depletion [3]. The use of conventional fishing restrictions (e.g., slot and bag limits and seasonal closures) in conjunction with small MPA's aimed specifically at protecting known spawning and nursery habitats may provide an effective alternative to large MPA's in fished areas.

Although a substantial amount of information is available concerning the ecology of top predators, significant knowledge gaps still remain. Little is known about the lifehistory and population sizes of most top predators in the PMNM, and the majority of existing studies are based on small sample sizes. These parameters are required for calculations of growth rate, mortality rate, and productivity, making them among the most important variables for understanding population dynamics [99]. An understanding of feeding periodicity, daily ration, inter-specific interactions, and the specific drivers of observed movement and distribution patterns will provide critical empirical data for parameterization of ecological models. These knowledge gaps could be filled by using a combination of classical techniques (e.g., mark recapture estimates of growth and abundance) and novel methods such as newly developed "ecology tags".

\section{Acknowledgment}

This study was funded by an award to the Hawaii Institute of Marine Biology from the National Marine Sanctuary Program (MOA 2005-008).

\section{References}

[1] A. M. Friedlander and E. E. DeMartini, "Contrasts in density, size, and biomass of reef fishes between the northwestern and the main Hawaiian islands: the effects of fishing down apex predators," Marine Ecology Progress Series, vol. 230, pp. 253264, 2002.

[2] N. K. Dulvy, R. P. Freckleton, and N. V. C. Polunin, "Coral reef cascades and the indirect effects of predator removal by exploitation," Ecology Letters, vol. 7, no. 5, pp. 410-416, 2004.

[3] Y. Sadovy and M. Domeier, "Are aggregation-fisheries sustainable? Reef fish fisheries as a case study," Coral Reefs, vol. 24, no. 2, pp. 254-262, 2005.

[4] H. Scales, A. Balmford, and A. Manica, "Impacts of the live reef fish trade on populations of coral reef fish off northern Borneo," Proceedings of the Royal Society B, vol. 274, no. 1612, pp. 989-994, 2007.

[5] E. E. DeMartini, A. M. Friedlander, S. A. Sandin, and E. Sala, "Differences in fish-assemblage structure between fished and unfished atolls in the northern Line Islands, central Pacific," Marine Ecology Progress Series, vol. 365, pp. 199-215, 2008. 
[6] S. A. Sandin, J. E. Smith, E. E. DeMartini et al., "Baselines and degradation of coral reefs in the Northern Line Islands," PLoS ONE, vol. 3, no. 2, Article ID e1548, 2008.

[7] I. D. Williams, W. J. Walsh, R. E. Schroeder, A. M. Friedlander, B. L. Richards, and K. A. Stamoulis, "Assessing the importance of fishing impacts on Hawaiian coral reef fish assemblages along regional-scale human population gradients," Environmental Conservation, vol. 35, no. 3, pp. 261-272, 2008.

[8] S. Clarke, Quantification of the trade in shark fins, Ph.D. thesis, Imperial College London, London, UK, 2003.

[9] H. Scales, A. Balmford, M. Liu, Y. Sadovy, and A. Manica, "Keeping bandits at bay?" Science, vol. 313, no. 5787, pp. 612 613, 2006.

[10] Q. S. W. Fong and J. L. Anderson, "International shark fin markets and shark management: an integrated market preference-cohort analysis of the blacktip shark (Carcharhinus limbatus)," Ecological Economics, vol. 40, no. 1, pp. 117-130, 2002.

[11] S. Clarke, Shark Product Trade in Hong Kong and Mainland China and implementation of the CITES Shark Listings, Traffic, Hong Kong, 2004.

[12] S. C. Clarke, J. E. Magnussen, D. L. Abercrombie, M. K. McAllister, and M. S. Shivji, "Identification of shark species composition and proportion in the Hong Kong shark fin market based on molecular genetics and trade records," Conservation Biology, vol. 20, no. 1, pp. 201-211, 2006.

[13] K. Warren-Rhodes, Y. Sadovy, and H. Cesar, "Marine ecosystem appropriation in the Indo-Pacific: a case study of the live reef fish food trade," Ambio, vol. 32, no. 7, pp. 481-488, 2003.

[14] M. L. Pace, J. J. Cole, S. R. Carpenter, and J. F. Kitchell, "Trophic cascades revealed in diverse ecosystems," Trends in Ecology and Evolution, vol. 14, no. 12, pp. 483-488, 1999.

[15] G. A. Polis, A. L. W. Sears, G. R. Huxel, D. R. Strong, and J. Maron, "When is a trophic cascade a trophic cascade?" Trends in Ecology and Evolution, vol. 15, no. 11, pp. 473-475, 2000.

[16] D. R. Bellwood, T. P. Hughes, C. Folke, and M. Nyström, "Confronting the coral reef crisis," Nature, vol. 429, no. 6994, pp. 827-833, 2004.

[17] K. T. Frank, B. Petrie, J. S. Choi, and W. C. Leggett, "Ecology: trophic cascades in a formerly cod-dominated ecosystem," Science, vol. 308, no. 5728, pp. 1621-1623, 2005.

[18] M. R. Heithaus, A. Frid, A. J. Wirsing, and B. Worm, "Predicting ecological consequences of marine top predator declines," Trends in Ecology and Evolution, vol. 23, no. 4, pp. 202-210, 2008.

[19] S. A. Sandin, S. M. Walsh, and J. B. C. Jackson, "Prey release, trophic cascades, and phase shifts in tropical nearshore ecosystems," in Trophic Cascades: Predators, Prey, and the Changing Dynamics of Nature, J. Terborgh and J. A. Estes, Eds., pp. 71-90, Island Press, Washington, DC, USA, 2010.

[20] R. R. Warner, "Traditionality of mating-site preferences in a coral reef fish,” Nature, vol. 335, no. 6192, pp. 719-721, 1988.

[21] S. R. Holzwarth, E. E. DeMartini, R. E. Schroeder, B. J. Zgliczynski, and J. L. Laughlin, "Sharks and jacks in the Northwestern Hawaiian Islands from towed-diver surveys 2000-2003," Atoll Research Bulletin, no. 543, pp. 257-279, 2006.

[22] Y. P. Papastamatiou, B. M. Wetherbee, C. G. Lowe, and G. L. Crow, "Distribution and diet of four species of carcharhinid shark in the Hawaiian Islands: evidence for resource partitioning and competitive exclusion," Marine Ecology Progress Series, vol. 320, pp. 239-251, 2006.
[23] F. A. Parrish and R. C. Boland, "Habitat and reef-fish assemblages of banks in the Northwestern Hawaiian Islands," Marine Biology, vol. 144, no. 6, pp. 1065-1073, 2004.

[24] A. E. Sudekum, J. D. Parrish, R. L. Radtke, and S. Ralston, "Life history and ecology of large jacks in undisturbed, shallow, oceanic communities," Fishery Bulletin, vol. 89, no. 3, pp. 493513, 1991.

[25] M. R. Heithaus, A. J. Wirsing, L. M. Dill, and L. I. Heithaus, "Long-term movements of tiger sharks satellite-tagged in Shark Bay, Western Australia," Marine Biology, vol. 151, no. 4, pp. 1455-1461, 2007.

[26] A. R. Everson, H. A. Williams, and B. M. Ito, "Maturation and reproduction in two Hawaiian eteline snappers, uku, Aprion virescens, and onaga, Etelis coruscans," Fishery Bulletin, vol. 87, no. 4, pp. 877-888, 1989.

[27] M. R. Heupel, L. M. Currey, A. J. Williams, C. A. Simpfendorfer, A. C. Ballagh, and A. L. Penny, "The comparative biology of Lutjanid species on the Great Barrier Reef. Project Milestone report," in Report to the Marine and Tropical Sciences Research Facility, pp. 1-30, Reef and Rainforest Research Centre Limited, Cairns, Australia, 2009.

[28] M. A. DeCrosta, L. R. Taylor, and J. D. Parrish, "Age determination, growth and energetics of three species of carcharinid sharks in Hawai'i," in Proceedings of the 2nd Symposium on Resource Investigations in the NWHI, R. W. Grigg and K. Y. Tanoue, Eds., vol. 2, pp. 75-95, University of Hawa'i Sea Grant, Honolulu, Hawa'i, USA, May 1984, UNIHI-SEA-GRANTMR-84-01.

[29] N. M. Whitney and G. L. Crow, "Reproductive biology of the tiger shark (Galeocerdo cuvier) in Hawa'i," Marine Biology, vol. 151, no. 1, pp. 63-70, 2007.

[30] B. M. Wetherbee, G. L. Crow, and C. G. Lowe, "Biology of the Galapagos shark, Carcharhinus galapagensis, in Hawai'i," Environmental Biology of Fishes, vol. 45, no. 3, pp. 299-310, 1996.

[31] S. E. Smith, D. W. Au, and C. Show, "Intrinsic rebound potentials of 26 species of Pacific sharks," Marine and Freshwater Research, vol. 49, no. 7, pp. 663-678, 1998.

[32] B. M. Wetherbee, G. L. Crow, and C. G. Lowe, "Distribution, reproduction and diet of the gray reef shark Carcharhinus amblyrhynchos in Hawa'i," Marine Ecology Progress Series, vol. 151, no. 1-3, pp. 181-189, 1997.

[33] R. C. Wass, A comparative study of the life history, distribution and ecology of the sandbar shark and the grey reef shark in Hawai'i, Ph.D. thesis, Department of Zoology, University of Hawa'i, Honolulu, Hawa'i, USA, 1971.

[34] B. M. Wetherbee, C. G. Lowe, and G. L. Crow, "A review of shark control in Hawa'i with recommendations for future research," Pacific Science, vol. 48, no. 2, pp. 95-115, 1994.

[35] J. G. Romine, R. D. Grubbs, and J. A. Musick, "Age and growth of the sandbar shark, Carcharhinus plumbeus, in Hawaiian waters through vertebral analysis," Environmental Biology of Fishes, vol. 77, no. 3-4, pp. 229-239, 2006.

[36] C. G. Meyer, T. B. Clark, Y. P. Papastamatiou, N. M. Whitney, and K. N. Holland, "Long-term movement patterns of tiger sharks Galeocerdo cuvier in Hawa'i," Marine Ecology Progress Series, vol. 381, pp. 223-235, 2009.

[37] C. G. Meyer, J. J. Dale, Y. P. Papastamatiou, N. M. Whitney, and K. N. Holland, "Seasonal cycles and long-term trends in abundance and species composition of sharks associated with cage diving ecotourism activities in Hawai'i," Environmental Conservation, vol. 36, pp. 104-111, 2009. 
[38] R. H. Lowe-McConnell, Ecological Studies in Tropical Fish Communities, University of Cambridge Press, 1987.

[39] A. M. DeMartini and S. A. Friedlander, "Spatial patterns of endemism in shallow-water reef fish populations of the Northwestern Hawaiian Islands," Marine Ecology Progress Series, vol. 271, pp. 281-296, 2004.

[40] J. E. Randall, Shore Fishes of Hawai'i, Natural World Press, Vida, Ore, USA, 1996.

[41] J. D. Stevens, "Life-history and ecology of sharks at Aldabra Atoll, Indian Ocean," Proceedings of the Royal Society of Biological Sciences B, vol. 222, no. 1226, pp. 79-106, 1984.

[42] J. E. Randall, P. S. Lobel, and E. H. Chave, "Annotated checklist of the fishes of Johnston Island," Pacific Science, vol. 39, pp. 2480, 1985.

[43] J. E. Randall, J. L. Earle, R. L. Pyle, J. D. Parrish, and T. Hayes, "Annotated checklist of the fishes of Midway Atoll, northwestern Hawaiian Islands," Pacific Science, vol. 47, no. 4, pp. 356-400, 1993.

[44] D. R. Robertson and G. R. Allen, "Zoogeography of the shorefish fauna of Clipperton Atoll," Coral Reefs, vol. 15, no. 2, pp. 121-131, 1996.

[45] G. R. Allen and D. R. Robertson, "An annotated checklist of the fishes of Clipperton Atoll, tropical eastern Pacific," Revista de Biologia Tropical, vol. 45, no. 2, pp. 813-843, 1997.

[46] P. S. Lobel and L. K. Lobel, "Annotated checklist of the fishes of Wake Atoll," Pacific Science, vol. 58, no. 1, pp. 65-90, 2004.

[47] L. V. Compagno, M. Dando, and S. Fowler, Sharks of the World, Princeton University Press, Princeton, NJ, USA, 2005.

[48] Y. P. Papastamatiou, J. E. Caselle, A. M. Friedlander, and C. G. Lowe, "Distribution, size frequency, and sex ratios of blacktip reef sharks Carcharhinus melanopterus at Palmyra Atoll: a predator-dominated ecosystem," Journal of Fish Biology, vol. 75, no. 3, pp. 647-654, 2009.

[49] C. G. Meyer, K. N. Holland, and Y. P. Papastamatiou, "Seasonal and diel movements of giant trevally Caranx ignobilis at remote Hawaiian atolls: implications for the design of marine protected areas," Marine Ecology Progress Series, vol. 333, pp. 13-25, 2007.

[50] J. J. Polovina, "Model of a coral reef ecosystem," Coral Reefs, vol. 3, no. 1, pp. 1-11, 1984.

[51] C. G. Meyer, Y. P. Papastamatiou, and K. N. Holland, "Seasonal, diel, and tidal movements of green jobfish (Aprion virescens, Lutjanidae) at remote Hawaiian atolls: implications for marine protected area design," Marine Biology, vol. 151, no. 6, pp. 2133-2143, 2007.

[52] C. G. Lowe, B. M. Wetherbee, and C. G. Meyer, "Using acoustic telemetry monitoring techniques to quantity movement patterns and site fidelity of sharks and giant trevally around French frigate shoals and midway atoll," Atoll Research Bulletin, no. 543, pp. 281-303, 2006.

[53] C. G. Meyer, Y. P. Papastamatiou, and K. N. Holland, "A multiple instrument approach to quantifying the movement patterns and habitat use of tiger (Galeocerdo cuvier) and Galapagos sharks (Carcharhinus galapagensis) at French Frigate Shoals, Hawa'i," Marine Biology, vol. 157, no. 8, pp. 1857$1868,2010$.

[54] K. N. Holland, B. M. Wetherbee, C. G. Lowe, and C. G. Meyer, "Movements of tiger sharks (Galeocerdo cuvier) in coastal Hawaiian waters," Marine Biology, vol. 134, no. 4, pp. 665-673, 1999.

[55] J. J. Polovina and B. B. Lau, “Temporal and spatial distribution of catches of tiger sharks, Galeocerdo cuvier, in the pelagic longline fishery around the Hawaiian Islands," Marine Fisheries Review, vol. 55, pp. 1-3, 1993.
[56] A. M. Friedlander, S. A. Sandin, E. E. DeMartini, and E. Sala, "Spatial patterns of the structure of reef fish assemblages at a pristine atoll in the central Pacific," Marine Ecology Progress Series, vol. 410, pp. 219-231, 2010.

[57] C. G. Meyer, Y. P. Papastamatiou, and T. B. Clark, "Differential movement patterns and site fidelity among trophic groups of reef fishes in a Hawaiian marine protected area," Marine Biology, vol. 157, no. 7, pp. 1499-1511, 2010.

[58] F. Williams, "Further notes on the biology of East African pelagic fishes of the families Carangidae and Sphyraenidae," East African Journal of Agriculture and Forestry, vol. 157, pp. 141-168, 1965.

[59] R. Bagnis, P. Mazellier, J. Bennett, and E. Christian, Fishes of Polynesia, Les Editions du Pacifique, Tahiti, France, 1972.

[60] H. von Westernhagen, "Observations on the natural spawning of Alectis indicus (Rüppell) and Caranx ignobilis (Forsk.) (Carangidae)," Journal of Fish Biology, vol. 6, no. 4, pp. 513516, 1974.

[61] R. E. Johannes, "Reproductive strategies of coastal marine fishes in the tropics," Environmental Biology of Fishes, vol. 3, no. 1, pp. 65-84, 1978.

[62] R. E. Johannes, Words of the Lagoon: Fishing and Marine Lore in the Palau District of Micronesia, University of California Press, Berkeley, Calif, USA, 1981.

[63] N. E. Kohler, J. G. Casey, and P. A. Turner, "NMFS cooperative shark tagging program, 1962-93: an atlas of shark tag and recapture data," Marine Fisheries Review, vol. 60, no. 2, pp. 187, 1998.

[64] M. R. Heithaus, "The biology of tiger sharks, Galeocerdo cuvier, in Shark Bay, Western Australia: sex ratio, size distribution, diet, and seasonal changes in catch rates," Environmental Biology of Fishes, vol. 61, no. 1, pp. 25-36, 2001.

[65] A. J. Wirsing, M. R. Heithaus, and L. M. Dill, "Tiger shark (Galeocerdo cuvier) abundance and growth in a subtropical embayment: evidence from 7 years of standardized fishing effort," Marine Biology, vol. 149, no. 4, pp. 961-968, 2006.

[66] M. W. Beck, JR. Heck K.L., K. W. Able et al., “The identification, conservation, and management of estuarine and marine nurseries for fish and invertebrates," BioScience, vol. 51, no. 8, pp. 633-641, 2001.

[67] M. R. Heupel, J. K. Carlson, and C. A. Simpfendorfer, "Shark nursery areas: concepts, definition, characterization and assumptions," Marine Ecology Progress Series, vol. 337, pp. 287-297, 2007.

[68] E. E. DeMartini, "Habitat and endemism of recruits to shallow reef fish populations: selection criteria for no-take MPAs in the NWHI coral reef ecosystem reserve," Bulletin of Marine Science, vol. 74, no. 1, pp. 185-205, 2004.

[69] C. G. Meyer, W. C. Burgess, Y. P. Papastamatiou, and K. N. Holland, "Use of an implanted sound recording device (Bioacoustic Probe) to document the acoustic environment of a blacktip reef shark (Carcharhinus melanopterus)," Aquatic Living Resources, vol. 20, no. 4, pp. 291-298, 2007.

[70] Y. P. Papastamatiou, C. G. Meyer, and K. N. Holland, "A new acoustic $\mathrm{pH}$ transmitter for studying the feeding habits of freeranging sharks," Aquatic Living Resources, vol. 20, no. 4, pp. 287-290, 2007.

[71] N. M. Whitney, Y. P. Papastamatiou, K. N. Holland, and C. G. Lowe, "Use of an acceleration data logger to measure diel activity patterns in captive whitetip reef sharks, Triaenodon obesus," Aquatic Living Resources, vol. 20, no. 4, pp. 299-305, 2007. 
[72] K. N. Holland, C. G. Meyer, and L. C. Dagorn, "Inter-animal telemetry: results from first deployment of acoustic 'business card' tags," Endangered Species Research, vol. 10, no. 1, pp. 287 293, 2010.

[73] R. M. Gooding, "Predation on released spiny lobster, Panulirus marginatus, during tests in the northwestern Hawaiian Islands," Marine Fisheries Review, vol. 47, no. 3, pp. 27-35, 1985.

[74] R. B. Moffitt, D. R. Kobayashi, and G. T. DiNardo, "Status of the Hawaiian Bottomfish Stocks, 2004," Pacific Islands Fisheries Science Center, National Marine Fisheries Service, Pacific Islands Fisheries Science Center Administrative Report H-06-01, NOAA, Honolulu, HI 96822-2396, 2006.

[75] M. P. Seki, "The food and feeding habits of the grouper, Epinephelus quernus Seale 1901, in the Northwestern Hawaiian Islands," in Proceedings of the 2nd Symposium on Resource Investigations in the Northwestern Hawaiian Islands, R. W. Grigg and K. Y. Tanoue, Eds., vol. 2, pp. 179-191, University of Hawa'i, Honolulu, Hawa'i, USA, May 1983, UNIHISEAGRANT-MR-84-01, 1984.

[76] J. D. Parrish, "Trophic biology of snappers and groupers," in Tropical Snappers and Groupers: Biology and Fisheries Management, J. J. Polovina and S. V. Ralston, Eds., Westview Press, Boulder, Colo, USA, 1987.

[77] W. R. Haight, J. D. Parrish, and T. A. Hayes, "Feeding ecology of deepwater lutjanid snappers at Penguin Bank, Hawa'i," Transactions of the American Fisheries Society, vol. 122, no. 3, pp. 328-347, 1993.

[78] R. L. Humphreys and S. H. Kramer, "Ciguatera and the feeding habits of the greater amberjack, Seriola dumerili, in the Hawaiian archipelago," in Proceedings of the 2nd Symposium on Resource Investigations in the Northwestern Hawaiian Islands, R. W. Grigg and K. Y. Tanoue, Eds., vol. 2, pp. 179-191, University of Hawa'i, Honolulu, Hawa'i, USA, May 1983, UNIHI-SEAGRANT-MR-84-01, 1984.

[79] C. G. Lowe, B. M. Wetherbee, G. L. Crow, and A. L. Tester, "Ontogenetic dietary shifts and feeding behavior of the tiger shark, Galeocerdo cuvier, in Hawaiian waters," Environmental Biology of Fishes, vol. 47, no. 2, pp. 203-211, 1996.

[80] G. A. Antonelis, J. D. Baker, T. C. Johanos, R. C. Braun, and A. L. Harting, "Hawaiian monk seal (Monachus schauinslandi): status and conservation issues," Atoll Research Bulletin, no. 543, pp. 75-101, 2006.

[81] A. L. Tester, "Cooperative shark research and control program," final report 1967-69, Department of Zoology, University of Hawa'i, Honolulu, Hawa'i, USA, 1969.

[82] G. G. Winberg, "Rate of metabolism and food requirements of fishes," Fisheries Research Board of Canada Translational Series, vol. 194, pp. 1-202, 1960.

[83] A. C. Gleiss, J. J. Dale, K. N. Holland, and R. P. Wilson, "Accelerating estimates of activity-specific metabolic rate in fishes: testing the applicability of acceleration data-loggers," Journal of Experimental Marine Biology and Ecology, vol. 385, no. 1-2, pp. 85-91, 2010.

[84] E. E. DeMartini, A. M. Friedlander, and S. R. Holzwarth, "Size at sex change in protogynous labroids, prey body size distributions, and apex predator densities at NW Hawaiian atolls," Marine Ecology Progress Series, vol. 297, pp. 259-271, 2005.

[85] S. Ralston and G. T. Miyamoto, "Analyzing the width of daily otolith increments to age the Hawaiian snapper, Pristipomoides filamentosus," Fishery Bulletin, vol. 81, no. 3, pp. 523-535, 1983.
[86] A. E. Economakis and P. S. Lobel, "Aggregation behavior of the grey reef shark, Carcharhinus amblyrhynchos, at Johnston Atoll, Central Pacific Ocean," Environmental Biology of Fishes, vol. 51, no. 2, pp. 129-139, 1998.

[87] D. Sims, J. Nash, and D. Morritt, "Movements and activity of male and female dogfish in a tidal sea lough: alternative behavioural strategies and apparent sexual segregation," Marine Biology, vol. 139, no. 6, pp. 1165-1175, 2001.

[88] E. E. DeMartini, F. A. Parrish, and J. D. Parrish, "Interdecadal change in reef fish populations at French frigate shoals and midway atoll, northwestern Hawaiian Islands: statistical power in retrospect," Bulletin of Marine Science, vol. 58, no. 3, pp. 804-825, 1996.

[89] E. E. DeMartini and A. M. Friedlander, "Predation, endemism, and related processes structuring shallow-water reef fish assemblages of the NWHI," Atoll Research Bulletin, no. 543, pp. 237-256, 2006.

[90] J. D. Stevens, R. Bonfil, N. K. Dulvy, and P. A. Walker, "The effects of fishing on sharks, rays, and chimaeras (chondrichthyans), and the implications for marine ecosystems," ICES Journal of Marine Science, vol. 57, no. 3, pp. 476-494, 2000.

[91] F. A. Parrish, G. J. Marshall, B. Buhleier, and G. A. Antonelis, "Foraging interaction between monk seals and large predatory fish in the Northwestern Hawaiian Islands," Endangered Species Research, vol. 4, no. 3, pp. 299-308, 2008.

[92] K. M. Duncan and K. N. Holland, "Habitat use, growth rates and dispersal patterns of juvenile scalloped hammerhead sharks Sphyrna lewini in a nursery habitat," Marine Ecology Progress Series, vol. 312, pp. 211-221, 2006.

[93] M. R. Heithaus and L. M. Dill, "Food availability and tiger shark predation risk influence bottlenose dolphin habitat use," Ecology, vol. 83, no. 2, pp. 480-491, 2002.

[94] J. S. Link, "What does ecosystem-based fisheries management mean?" Fisheries, vol. 27, pp. 18-21, 2002.

[95] J. M. Pandolfi, R. H. Bradbury, E. Sala et al., "Global trajectories of the long-term decline of coral reef ecosystems," Science, vol. 301, no. 5635, pp. 955-958, 2003.

[96] J. Wolfenden, F. Cram, and B. Kirkwood, "Marine reserves in New Zealand: a survey of community reactions," Ocean and Coastal Management, vol. 25, no. 1, pp. 31-51, 1994.

[97] C. Cocklin, M. Craw, and I. Mcauley, "Marine reserves in New Zealand: use rights, public attitudes, and social impacts," Coastal Management, vol. 26, no. 3, pp. 213-231, 1998.

[98] T. Agardy, P. Bridgewater, M. P. Crosby et al., "Dangerous targets? Unresolved issues and ideological clashes around marine protected areas," Aquatic Conservation: Marine and Freshwater Ecosystems, vol. 13, no. 4, pp. 353-367, 2003.

[99] E. Cortés, "Demographic analysis of the Atlantic sharpnose shark, Rhizoprionodon terraenovae, in the Gulf of Mexico," Fishery Bulletin, vol. 93, no. 1, pp. 57-66, 1995. 

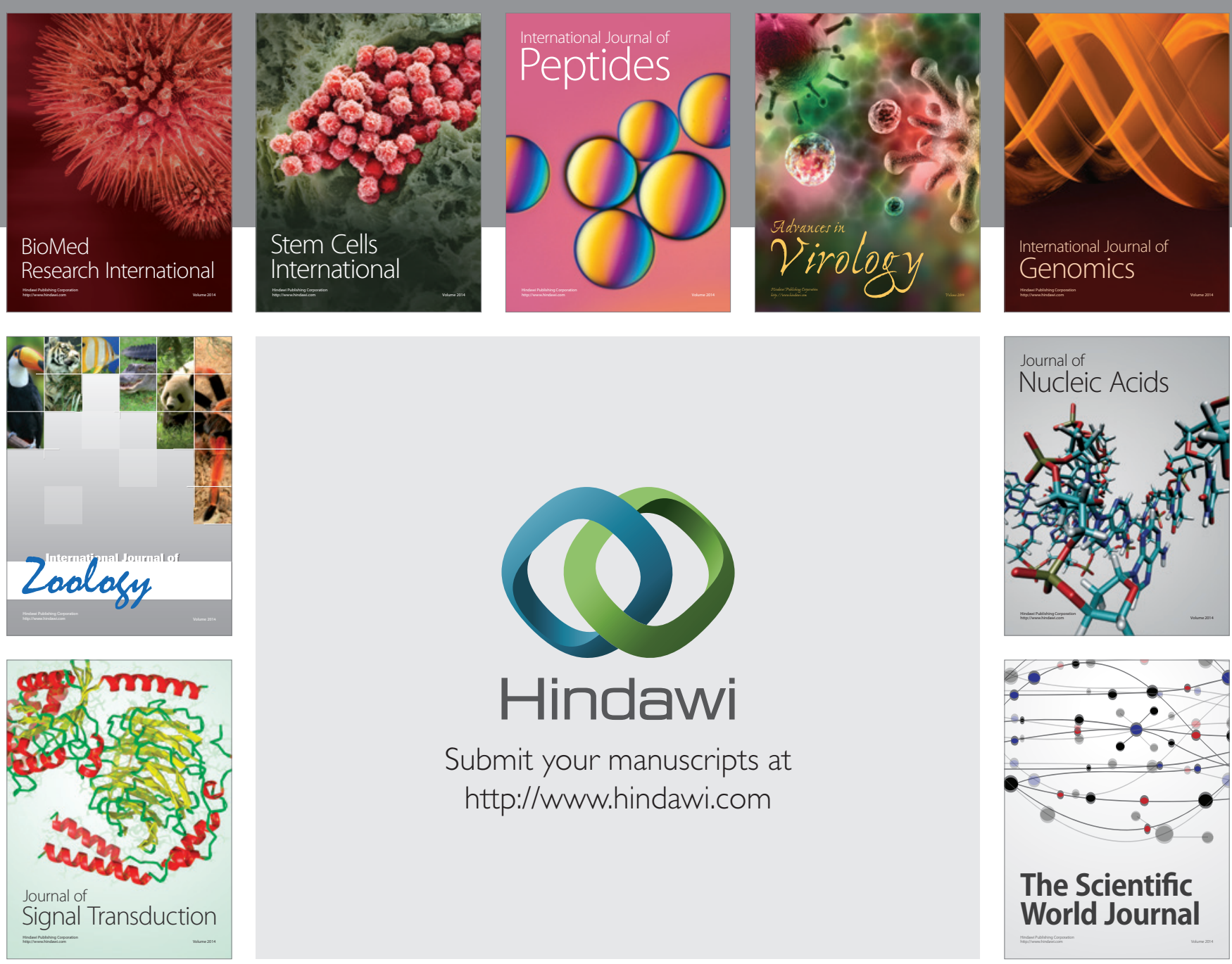

Submit your manuscripts at

http://www.hindawi.com
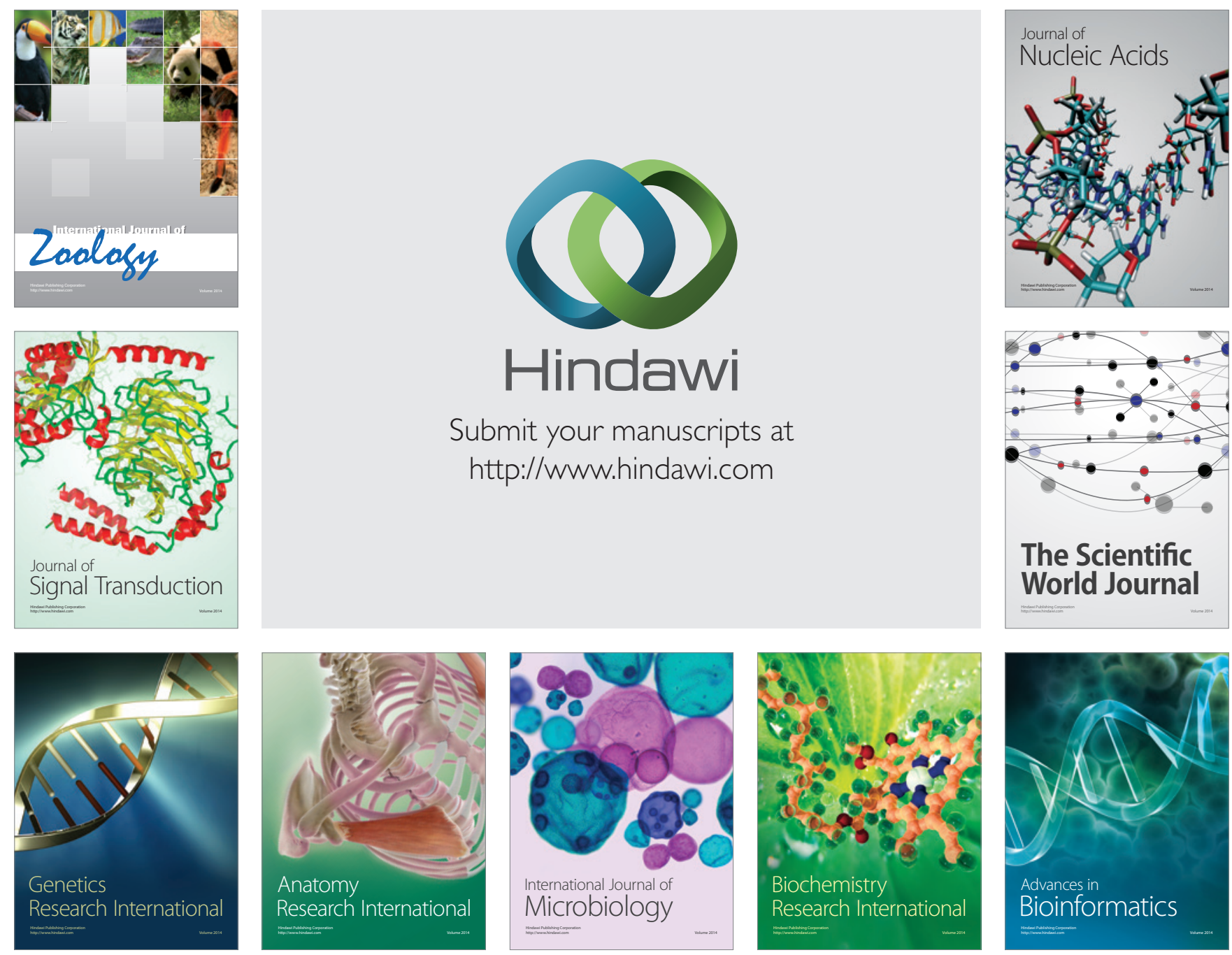

The Scientific World Journal
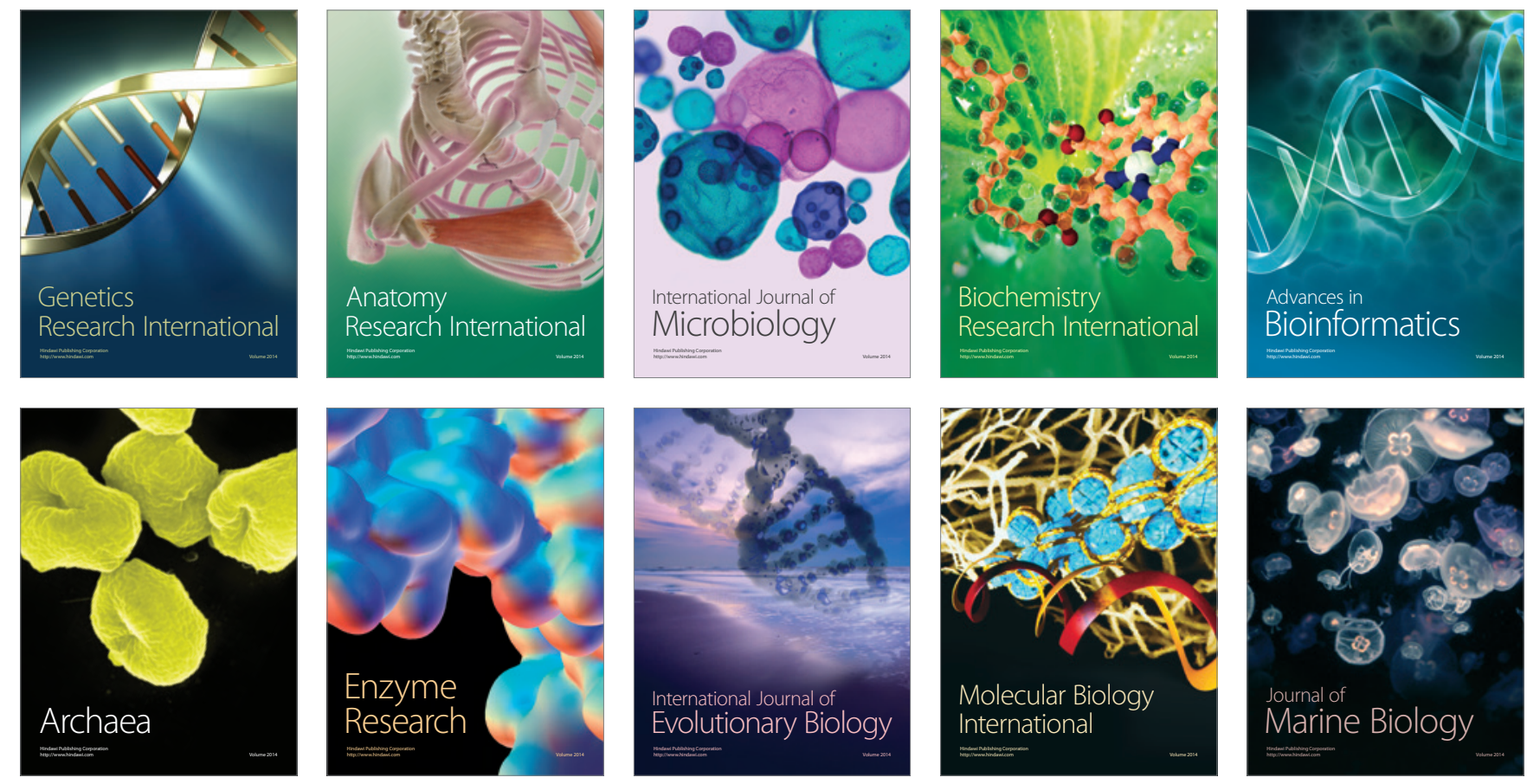